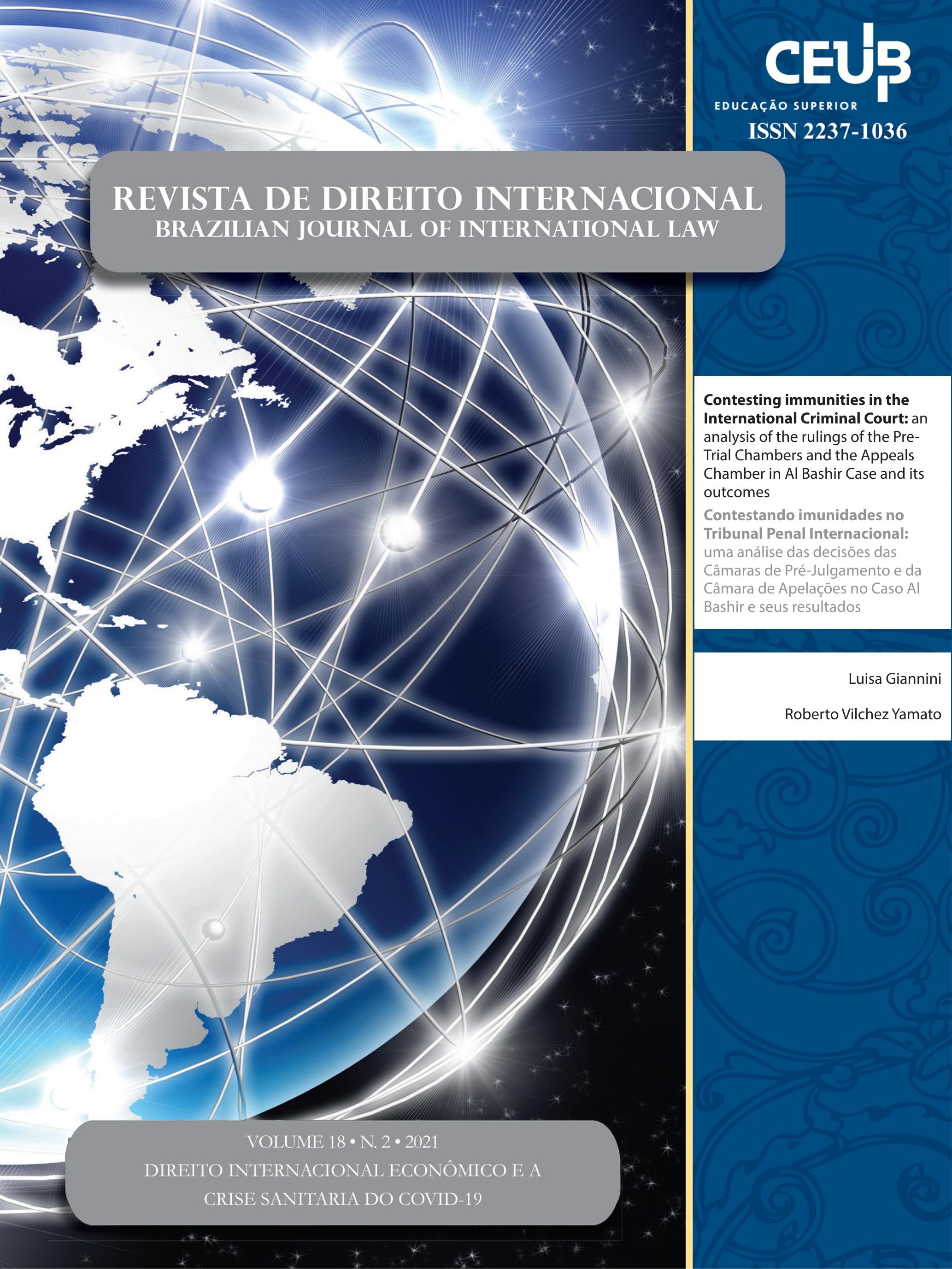




\section{Sumário}

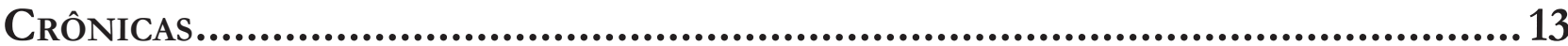

REIMAgining INTERNATIONAL RELATIONS TEACHING DURING (AND AFTER) COVID-19 ........15 Magdalena Bas

Dossiê Temático: Direito Internacional Econômico e a Crise sanitaria Do COVID-19 (INTERNATIONAL ECONOMic LaW AND THE COVID-19 SANITARY CRISIS) 19

Some QUESTIONS ABOUt INTERNATIONAL ECONOMic LAW RAISED DURING THE PANDEMIC .....21 Hervé Ascensio

International Economic LaW and the COVID-19 Sanitary Crisis: An Introduction 27 Julien Chaisse

TransparênCIA E COOPERAÇão REgUlatóRIA No COMÉRCIO INTERNACIONAL DE PRODUTOS MÉDicos PaRa a COVID-19: uMa ANÁlISE da ATUAÇão INSTITUCIONAL DA OMC E DAS NOTIFICAÇõES do Brasil EM OBSERVÂNCIA AOS ACordos TBT E SPS .35

Magali Favaretto Prieto Fernandes e Michelle Ratton Sanchez Badin

O DEVER HUMANO DE PROMOÇÃo DA SAÚDE: A AVIAÇÃo COMERCIAL INTERNACIONAL EM PERÍODOS DE CALAMIDADE SANITÁRIA E DO RETORNO À NORMALIDADE .56

Thiago de Oliveira Frizera, Luisa Cortat Simonetti Gonçalves e Adriano Sant'Ana Pedra

Police Powers Doctrine: a reliable State Defense in times of Covid-19?.... .73 Thomas Lehmann

A inexistênCia do Controle preventivo legislativo de Convencionalidade da Medida Provisória n. ${ }^{\circ} 936 / 2020$ .91

Danilo Garnica Simini, Gabriel Carvalho Moreira e Rafaela Souza Machado 
A Critical analysis of the implications of Covid-19 on piracy off the Nigerian COAST

Kalu Kingsley Anele

The COVID-19 PANDEMIC AS AN IMPELlER FOR THE AGgRAVATION OF MARINE PLASTIC POLLUTION AND ECONOMIC CRISIS: THE REVERSE EFFECT OF HEALTH PROTECTION MEASURES ON HUMAN LIVES 135

Adriana Isabelle Barbosa Lima Sá Leitão e Tarin Cristino Frota Mont’Alverne

Artigos sobre outros temas

O Direito Internacional Humanitário nos Pareceres Consultivos da Corte Internacional de Justiça: uma Conjugação de Perspectivas Utópicas e Apologéticas 156

Talis Prado Pinto Junior e Arthur Roberto Capella Giannattasio

Contesting immunities in the International Criminal Court: an analysis of the RUlings of the Pre-Trial Chambers and the Appeals Chamber in Al Bashir Case and its OUTCOMES. 171

Luisa Giannini e Roberto Vilchez Yamato

Rumo à Profissionalização da Prevenção de Controvérsias nos Acordos de CooperaÇão e Facilitação de InVEstimentos (ACFIs) do Brasil? 191

Nitish Monebhurrun e Leonardo Vieira Arruda Achtschin

THE PREVENTIVE CHARACTER OF DISASTER LAW: TAX INCENTIVES IN ENVIRONMENTAL, SOCIAL, AND GOVERNANCE (ESG) INVESTMENTS AS A RISK MITIGATION MECHANISM 212

Daniel Dela Coleta Eisaqui e Deilton Ribeiro Brasil

A URGÊNCIA DE UM MODELO DE GOVERNANÇA INTERNACIONAL DA ÁGUA: ELEMENTOS PARA A DISCUSSÃO

José Irivaldo Alves Oliveira Silva

O FIM DA HIERARQUIA SUPRALEgAL DOS TRATADOS INTERNACIONAIS: ANÁLISE DA ADI N.O 5.543/2020-DF: À luZ dA TeOria ARgumentativa de Neil Maccormick. 
Os DIREITOS HUMANOS FRENTE À NORMATIVIDADE “IMPERIAL" E A RESPONSABILIDADE DAS EMPRESAS TRANSNACIONAIS POR VIOLAÇÃO AOS DIREITOS HUMANOS NA ERA DO “IMPÉRIO” 280

Fernando Hoffmam e Jose Luis Bolzan de Morais

O RECONHECIMENTO FACIAL NAS SMART CITIES E A GARANTIA DOS DIREITOS À PRIVACIDADE E À PROTEÇÃO DE DADOS PESSOAIS.. 302

Diogo Dal Magro e Vinícius Borges Fortes

O DESENVOLVIMENTO HISTÓRICO DA PROSCRIÇÃo DO DESAPARECIMENTO FORÇADO DE PESSOAS E sua fenomenologia no Direito Penal Internacional e no Direito Internacional dos Direitos Humanos

Marcus Vinícius Xavier de Oliveira

CONSTITUCIONALISMO COOPERATIVO GLOBAL E DIREITO INTERNACIONAL PRIVADO: INSTRUMENTOS PARA UMA GOVERNANÇA DE DIREITO TRANSNACIONAL NA INTEGRAÇÃO. 362

Anderson Vichinkeski Teixeira, Roberto Correia da Silva Gomes Caldas e Luciane Klein Vieira

Proteção da inovação pela aplicaÇão do Direito da ConcorrênCia da União Europeia: ANÁLISE DA INDÚSTRIA FARMACÊUTICA.

Pablo Leurquin 


\title{
Contesting immunities in the International Criminal Court: an analysis of the rulings of the Pre-Trial Chambers and the Appeals Chamber in Al Bashir Case and its outcomes*
}

\author{
Contestando imunidades no Tribunal Penal \\ Internacional: uma análise das decisões das \\ Câmaras de Pré-Julgamento e da Câmara de \\ Apelações no Caso Al Bashir e seus resultados
}

Luisa Giannini**

Roberto Vilchez Yamato***

\begin{abstract}
This article aims to examine the rulings of the International Criminal Court's Pre-Trial Chambers and Appeals Chamber regarding the relationship between the law of immunities, in particular heads of state immunity, and the exercise of jurisdiction by international criminal courts in the context of the Al Bashir Case. In terms of methodology, this investigation analyses these decisions highlighting the manner through which the chambers engaged with the legal reasonings presented especially by states. Through this examination, it seeks to identify the different forms of contestation from the actors in the field of international criminal law that were triggered by these rulings in a way that it is possible to make a correlation amongst the degree of engagement of the Chamber with outside arguments and the reaction it provoked. The article concludes that the different ways the Court deals with external actors and their reasonings will generate distinct kinds of responses, meaning that if these actors feel that the rulings are disregarding their arguments a more productive type of contestation can become an objection to the authority or legitimacy of the Court.
\end{abstract}

Keywords: Al Bashir Case; Immunities of Heads of State; International Criminal Court; Contestation; African Union; Pre-Trial Chamber; Appeals Chamber.

** Doctoral candidate at the Institute of International Relations at the Pontifical Catholic University of Rio de Janeiro (IRI/PUC-Rio). Researcher at the Centre for the Study of International Courts at the University of São Paulo (NETI-USP).

Email: luisa.giannini@gmail.com

*** Professor at the Institute of International Relations at the Pontifical Catholic University of Rio de Janeiro (IRI/PUC-Rio). Holds a PhD in International Relations from IRI/PUC-Rio (2011). PhD Candidate in Law at Birkbeck, University of London.

E-mail: robertoyamato@puc-rio.br

\section{Resumo}

O presente artigo tem por objetivo examinar as decisões das Câmaras de Pré-Julgamento e da Câmara de Apelações do Tribunal Penal Internacional sobre a relação entre a lei de imunidades, em particular a imunidade de chefes de estado, e o exercício da jurisdição por tribunais criminais internacionais no contexto do Caso $\mathrm{Al}$ Bashir. No que tange à metodologia, essa investigação realiza uma análise dessas decisões, destacando a forma como as câmaras se engajam com os raciocínios jurídicos apresentados prin- 
cipalmente pelos estados. Através desse exame, o artigo busca identificar as diferentes formas de contestação dos atores do campo do direito internacional penal que foram desencadeadas por essas decisões de forma que seja possível fazer uma correlação entre o grau de engajamento da Câmara com argumentos externos e a reação que provocou. $\mathrm{O}$ artigo conclui que as diferentes formas como o Tribunal trata os atores externos e seus raciocínios ocasionarão diferentes tipos de respostas, o que significa que, se esses atores sentirem que as decisões estão desconsiderando seus argumentos, um tipo mais produtivo de contestação pode se tornar uma objeção à autoridade ou legitimidade do Tribunal.

Palavras-chave: Caso Al Bashir; Imunidades de Chefes de Estado; Tribunal Penal Internacional; Contestação; União Africana; Câmara de Pré-Julgamento; Câmara de Apelações.

\section{Introduction}

Many renowned scholars in the field of international criminal law have recognised that the manner through which the International Criminal Court (ICC) has dealt with the issue of head of state immunity in the last decade has had a profound impact on its authority and legitimacy. ${ }^{1}$ This is the result of a chain of reactions that, more or less, started with the two arrest warrants issued by the ICC against the then sitting Head of State of Sudan, Omar Al Bashir.

Facing a sequence of non-compliances with its requests for the arrest and surrender of Bashir by its member states, the Court saw itself in the position of needing to issue decisions that would affirm and explain the need for these states to comply with its rulings. Nevertheless, these were considered unsatisfactory answers to the problem. They were not only disappointing and,

\footnotetext{
1 AKANDE, Dapo. The Immunity of Heads of States of Nonparties in the Early Years of the ICC, AJIL Unbound, v. 112, p. 172-176, 2018. This article does not seek in any way to measure the legitimacy or the authority of the ICC. The terms are used here in a broad fashion to evaluate the impact of certain practices. Even though we consider the way the Court has dealt with the Al Bashir Case affects how actors perceive it, we acknowledge that a comprehensive analysis on the Court's authority and legitimacy must take into account other factors that affect its effectiveness. In that sense, see for example: GONZÁLEZ-RUIZ, Cristián D.; MIJARES, Víctor M., Los fuertes hacen lo que quieren: exponiendo los límites de la Corte Penal Internacional, Revista de Direito Internacional, v. 17, n. 1, 2020.
}

at times, misleading, but also provided four different ways for grounding the argument that $\mathrm{Al} \mathrm{Bashir} \mathrm{was}$ not entitled to immunity before the ICC and, therefore, these states were under the obligation to comply with the arrest warrants. ${ }^{2}$

The present article seeks to investigate whether these answers given by ICC to the immunity challenges presented in the $\mathrm{Al}$ Bashir Case have had an impact on the kind of practices of contestation directed towards the Court. To account for the actual effects of these contestations, it is crucial to understand the intentions that drive such actions. It is the purpose of this analysis to map the patterns and forms of contestation directed towards the Court. For qualifying the process of contestation in a way that we can acknowledge their different objectives, discern the array of triggers and, finally, identify their consequences for the ICC, we will use the framework developed by Madsen, Cebulak and Wiebusch. ${ }^{3}$

Through this analysis, we seek to argue that the ICC, with its unsatisfactory rulings and lack of engagement with the contestation stemming from the vast range of actors from the field, have turned reactions that would otherwise be mere engagements with its case-law into challenges to the authority and legitimacy of the court. For this purpose, this article unfolds in the following way: section 2 engages in a brief overview of the relevant case law on the immunities of heads of state and other high-ranking officials to present its findings that will be contrasted later with its use by the Chambers of the ICC; the ensuing section turns the gaze to the practices from and surrounding the ICC in three moments, first in the Pre-Trial Chamber's (PTC) rulings for situations of non-compliance with its arrest warrants, second in the process initiated by the Appeals Chamber (AC) of opening the Court to external voices and the decision that culminated from it and third the reactions outside the court to the findings of these chambers; section 4 analyses the events presented in the previous segment to establish a correlation between the postures adopted by the ICC and the kinds of contestation that

\footnotetext{
2 AKANDE. The Immunity of Heads of States of Nonparties in the Early Years of the ICC.

3 MADSEN, Mikael Rask; CEBULAK, Pola; WIEBUSCH, Micha. Backlash against international courts: explaining the forms and patterns of resistance to international courts, International Journal of Law in Context, v. 14, n. 2, p. 197-220, 2018.
} 
it generated; the final section presents some concluding remarks.

\section{The issue of immunity of heads of state in international criminal courts}

The Case against Omar Al Bashir at the ICC has been a challenging one from the outset. He was the first sitting Head of State to have issued an arrest warrant by the ICC. ${ }^{4}$ However, this was not the first time the issue of a head of state or any other high-ranking official in office wanted to for trial for the perpetration of international crimes has arisen. Some cases have become landmarks when the topic of immunities for heads of state or other high-ranking officials emerges. Their importance is mainly due to the status of immunities as customary international law, therefore liable to change according to the practices of states and the opinio juris of authorities in the field. When it comes to trials for international crimes in international criminal jurisdictions, there are not many references to draw from, one of the reasons why taking such measures is a difficult path. ${ }^{5}$

\footnotetext{
4 In 2011, the Court issued a summons to appear to Kenyan politician Uhuru Kenyatta, who would become president in 2013. PRE-TRIAL CHAMBER II, Decision on the Prosecutor's Application for Summonses to Appear for Francis Kirimi Muthaura, Uburu Muigai Kenyatta and Mohammed Hussein Ali, The Hague: International Criminal Court (ICC), 2011. The case, however, was dropped in 2015 due to lack of evidence. TRIAL CHAMBER V, Decision on the withdrawal of charges against $\mathrm{Mr}$ Kenyatta, The Hague: International Criminal Court (ICC), 2015. The only other time the ICC has issued an arrest warrant against a sitting head of state was in 2011 for Libya's president Muammar Gaddafi. PRE-TRIAL CHAMBER I, Warrant of Arrest for Muammar Mobammed Abu Minyar Gaddafi, The Hague: International Criminal Court (ICC), 2011. The case of Kenyatta was different from the proceedings against Gaddafi and Bashir, since in the case of the latter two they were heads of states not party to the ICC Statute, which generates a series of questions regarding the nature of the ICC's jurisdiction over non-party states referred by the United Nations Security Council. For more on this topic, see AKANDE, D., The Legal Nature of Security Council Referrals to the ICC and its Impact on Al Bashir's Immunities, Journal of International Criminal Justice, v. 7, n. 2, p. 333-352, 2009. AKANDE, Dapo. Who Is Obliged to Arrest Bashir?, EJIL: Talk!!, Available at: http:/ / www.ejiltalk.org/the-african-union-the-icc-and-universal-jurisdiction-some-recent-developments/. Accessed: 5 Aug. 2020. GAETA, P., Does President Al Bashir Enjoy Immunity from Arrest?, Journal of International Criminal Justice, v. 7, n. 2, p. 315-332, 2009. PAPILLON, Sophie, Has the United Nations Security Council Implicitly Removed Al Bashir's Immunity?, International Criminal Law Review, v. 10, n. 2, p. 275-288, 2010.

5 In the general debate, it is widely defended that the violation of
}

The experience of the International Criminal Tribunal for the former Yugoslavia (ICTY) was of utmost importance in the developing of the range of immunities for state officials in international law. There, the discussion of immunities occurred in more than one of its cases, since most of the tried individuals held positions that would entitle them to immunities. The case in the ICTY that raised most attention for the issue of immunities was the one against Slobodan Milošević, the former president of Serbia. Once the amici curiae posed the question of Miloševićs entitlement to immunities - which had the point of questioning the ICTY's authority and competence to prosecute the defendant -, the Trial Chamber its decision referred to both ICC's Rome Statute and the International Law Commission's Draft Code of Crimes against the Peace and Security of Mankind to highlight the "customary character of the rule that a Head of State cannot plead his official position as a bar to criminal liability in respect of crimes over which the International Tribunal has jurisdiction."

However, other cases in the ICTY also debated the issue of immunities. In the Blaškić Case, the Appeals Chamber, presided by Judge Antonio Cassese, affirmed that there are exceptions in the implementation of the law of immunities posed by "norms of international criminal law prohibiting war crimes, crimes against humanity and genocide. Under these norms, those responsible for such crimes cannot invoke immunity from national or international jurisdiction even if they perpe-

jus cogens norms would be enough to withstand the waiver of sovereign immunities. Nevertheless, the practice of international law shows a much more nuanced set of positions. The issue of whether human rights norms with a jus cogens character justify the removal of immunity was discussed by the International Court of Justice in the Jurisdictional Immunities of the State Case in which the Court understood that there is no conflict between immunity and jus cogens norms. ALMEIDA, Paula Wojcikiewicz, Imunidades jurisdicionais do Estado perante a Corte Internacional de Justiça: uma análise a partir do caso Alemanha vs. Itália, Revista Direito GV, v. 12, n. 2, p. 516-541, 2016; LARA ABREU, Patrícia Maria; BASTOS RAPOSO, Rodrigo, Imunidade de jurisdição do Estado e reparação civil pela prática de tortura: o caso Zahra Kazemi v. República Islâmica do Irã, Revista de Direito Internacional, v. 11, n. 2, 2015; KALLÁS E CAETANO, Fernanda Araújo. A imunidade de jurisdição das Organizações Internacionais face ao direito de acesso à justiça. Revista de Direito Internacional, v. 13, n. 3, 2017, p. 393; Jurisdictional Immunities of the State (Germany v. Italy: Greece intervening), The Hague: International Court of Justice (ICJ), 2012. para. 93.

6 TRIAL CHAMBER. Prosecutor v. Slobodan Milosevic, Decision on Preliminary Motions, The Hague: International Criminal Tribunal for the former Yugoslavia (ICTY), 2001. para. 31. 
trated such crimes while acting in their official capacity." The case against Karadžić, Mladić and Stanišić had the defence requesting that the Court deferred its jurisdiction in favour of a national tribunal, which prompted an answer from the ICTY's Trial Chamber stating that there was not any impediment for its exercise of jurisdiction since the official position of these individuals either in government or the military would pose no obstacle for the exercise of criminal responsibility by the ICTY. ${ }^{8}$ The Appeals Chamber in the Kristic case raised the point that no official would be granted immunity before an international criminal court, meaning that neither immunity ratione personae for Heads of State and other officials in office, nor immunity ratione materiae for former officials of the state, in cases where crimes under international law were committed would be admissible before criminal proceeding in the ICTY. ${ }^{9}$

Although it was recognised, in general, as an international court, ${ }^{10}$ the ICTY was still different from the ICC. While the first had an ad hoc nature and was created by UNSC Resolutions, the ICC is a treaty-based court. This means that the ICTY was acting under the authority of Chapter VII of the United Nations Charter, which would grant it the capacity to impose obligations to all UN members, encompassing the creation of obligations to arrest and surrender individuals wanted by the Court. Even though these differences would mean that it is not a question of merely transposing the principles consecrated by the ICTY to the ICC, it is essential to revisit the jurisprudence of the ICTY (together with the International Criminal Tribunal for Rwanda (ICTR)) because it helped in the setting of the foundations upon which other international criminal tribunals would ope-

APPEALS CHAMBER. Prosecutor v. Tihomir Blaskic, Judgement on the Request of the Republic of Croatia for Review of the Decision of Trial Chamber II of 18 July 1997, The Hague: International Criminal Tribunal for the former Yugoslavia (ICTY), 1997. para. 41.

8 TRIAL CHAMBER. In re Radovan Karad zici, Ratko Mladic and Mićo Stanisici, Decision in the Matter of a Proposal for a Formal Request for Deferral to the Competence of the Tribunal Addressed to the Republic of Bosnia and Herzegovina, The Hague: International Criminal Tribunal for the former Yugoslavia (ICTY), 1995. The jurisdiction of the ICTY worked differently from the ICC's. While the latter works based on the principle of complementarity, the former had the preference of hosting the trials over the domestic jurisdictions.

9 PEDRETTI, Ramona. Immunity of heads of state and state officials for international crimes, Leiden ; Boston: Brill Nijhoff, 2015. p. 255.

10 For more on the discussion on the characterization of international criminal courts, see SCHABAS, William A. The Special Tribunal for Lebanon: Is a 'Tribunal of an International Character' Equivalent to an 'International Criminal Court'?, Leiden Journal of International Law, v. 21, n. 2, p. 513-528, 2008. rate, including the establishment into customary international law of the possibility of criminal responsibility for heads of state and other high-ranking officials.

The International Court of Justice (ICJ), in the $A r$ rest Warrant Case, ${ }^{11}$ demonstrated not to have such an absolute position as the ICTY. The Court was careful as "to avoid a ruling that would reinforce impunity," 12 but at the same time did not affirm that the law on immunities is never applicable in the face of an international criminal court. The ICJ's ruling listed the scenarios in which immunities would not pose a barrier to criminal responsibility. Immunities for heads of state or other high-ranking state officials under international law would not stand in situations where these leaders are tried in their own countries and before foreign jurisdictions, but, in this second case, only if their state waives their immunities. Officials that are no longer serving their country are also not entitled to immunities related to acts perpetrated before or after their time in office. The last scenario discussed by the ICJ is perhaps the one that clearly shows that it does not want to have an unmitigated position regarding the existence of immunities before international criminal courts. ${ }^{13}$ In this matter, the ICJ affirms that

$[\mathrm{A}] \mathrm{n}$ incumbent or former Minister for Foreign Affairs may be subject to criminal proceedings before certain international criminal courts, where they have jurisdiction. Examples include the International Criminal Tribunal for the former Yugos-

${ }_{11}$ In this article, we will make reference only to the elements of the Arrest Warrant Case that are of importance to the discussion of immunities before the ICC. For a detailed analysis of this decision, see BASSIOUNI, M. Cherif, UNIVERSAL JURISDICTION UNREVISITED: THE INTERNATIONAL COURT OF JUSTICE DECISION IN CASE CONCERNING THE ARREST WARRANT OF 11 APRIL 2000 (DEMOCRATIC REPUBLIC OF THE CONGO V BELGIUM). The Palestine Yearbook of International Law, v. 12, n. 1, p. 27-48, 2002; WOUTERS, Jan, The Judgement of the International Court of Justice in the Arrest Warrant Case: Some Critical Remarks. Leiden Journal of International Law, v. 16, n. 2, p. 253-267, 2003; BOISTER, N., The ICJ in the Belgian Arrest Warrant Case: Arresting the Development of International Criminal Law. Journal of Conflict and Security Law, v. 7, n. 2, p. 293-314, 2002; YAMATO, Roberto Vilchez, Mandado de Prisão de 11 de Abril de 2000 (República Democrática do Congo vs. Bélgica) (14 de Fevereiro de 2002), in: RORIZ, João Henrique Ribeiro; AMARAL JÚNIOR, Alberto do (org.), O direito internacional em movimento: jurisprudência internacional comentada: Corte Internacional de Justiça e Supremo Tribunal Federal. Brasília: IBDC, 2016. p. 115-137.

12 PEDRETTI. Immunity of heads of state and state officials for international crimes, p. 130.

13 Arrest Warrant of 11 April 2000 (Democratic Republic of the Congo v. Belgium), The Hague: International Court of Justice (ICJ), 2002. para. 61. 
lavia, and the International Criminal Tribunal for Rwanda, established pursuant to Security Council resolutions under Chapter VII of the United $\mathrm{Na}$ tions Charter, and the future International Criminal Court created by the 1998 Rome Convention. The latter's Statute expressly provides, in Article 27, paragraph 2 , that ' $[i]$ mmunities or special procedural rules which may attach to the official capacity of a person, whether under national or international law, shall not bar the Court from exercising its jurisdiction over such a person. ${ }^{14}$

While in this last situation it is clearly stated that immunities would not stand in the way of tribunals established by the UN Security Council, as is the case of the ICTY and ICTR, the answer given by the ICJ left open the possibility of some immunities barring the exercise of jurisdiction by an international criminal court.

The decision of the Arrest Warrant Case was revisited, in 2004, in a ruling by the Appeals Chamber of the Special Court for Sierra Leone (SCSL) in the trial of Charles Taylor, who was President of Liberia. However, it was a somewhat controversial interpretation. Instead reaffirming the notion that state officials "retain their personal immunities before courts (especially national courts) even when there are allegations of international crimes," "15 the Appeals Chamber of the SCSL concluded that heads of state and other state officials would not be entitled to personal immunities before international criminal courts. ${ }^{16}$

Another trial against a sitting head of state was the one against Hissène Habré, Chad's former Head of State, in the Extraordinary African Chambers, a court established in Senegal through an agreement between Senegal and the African Union (AU). Nonetheless, the issue of immunity was not raised, since Chad had waived Habré's immunities in 2002. ${ }^{17}$

The effort of looking back into these cases that debated the existence of personal immunities for heads of state and other high-ranking state officials in office has

\footnotetext{
14 INTERNATIONAL COURT OF JUSTICE (ICJ). Arrest Warrant of 11 April 2000 (Democratic Republic of the Congo v. Belgium), The Hague: [s.n.], 2002. para. 61.

15 CRYER, Robert. Prosecuting the Leaders: Promises, Politics and Practicalities. Goettingen Journal of International Law, p. 64, 2009.

16 APPEALS CHAMBER. Prosecutor v. Taylor, Decision on Immunity from Jurisdiction, Freetown: Special Court for Sierra Leone (SCSL), 2004. para. 51.

17 SWART, Mia. The African Pinochet? Universal Jurisdiction and the Habré Case. In: WEILL, Sharon; SEELINGER, Kim Thuy; CARLSON, Kerstin Bree (org.). The President on Trial: Prosecuting Hissène Habré. Oxford: Oxford University Press, 2020. p. 410.
}

the purpose of understanding the (lack of) structured arguments posed by these international/hybrid criminal courts. This is important considering that one of the goals of this article is to analyse the reasoning given by the chambers of the ICC to corroborate their position that Bashir is not entitled to personal immunities in the face of its jurisdiction and these arguments are many times characterised by flawed legal reasoning. ${ }^{18}$

\section{The issue of Immunity of Head of State in the Al Bashir Case at the ICC}

It is considered that one of the greatest and most significant achievements in the drafting of the Rome Statute is article 27 , which represents a massive win in the fight against impunity for perpetrators of international crimes. Including this article in the constitutive treaty of the ICC meant that no head of state or other high-ranking officials from a member state could raise their immunities against the exercise of jurisdiction by the ICC, rendering the official capacity of the accused irrelevant in the face of criminal proceedings before the Court. ${ }^{19}$ While article $27(1)$ deals with immunities ratione materiae, article 27(2) deems irrelevant immunities ratione personae. ${ }^{20}$

Despite being a great accomplishment for the Court, article 27 does not set the tone of the ICC's Rome Statute in its entirety. In contrast to the provisions of article 27 , there is article 98 . In a very different spirit, article 98 seems to bring back the immunities deemed irrelevant in article 27 , when it declares that " $[t]$ he Court may not proceed with a request for surrender or assistance which would require the requested state to act inconsistently with its obligations under international law with respect to the State or diplomatic immunity of a person" 21 or "would require the requested State to act inconsistently with its obligations under international agreements pursuant to which the consent of a sending

\footnotetext{
18 KJELDGAARD-PEDERSEN, Astrid. Is the Quality of the ICC's Legal Reasoning an Obstacle to Its Ability to Deter International Crimes?, iCourts Working Paper Series, n. 191, 2020.

19 TRIFFTERER, Otto; BURCHARD, Christoph. Article 27 Irrelevance of official capacity, in: TRIFFTERER, Otto; AMBOS, Kai (org.). Rome Statute of the International Criminal Court: a commentary. Third edition. München: C.H. Beck, 2016. p. 1038.

20 Rome Statute of the International Criminal Court, Rome: [s.n.], 1998. article 27.

21 Rome Statute of the International Criminal Court, article 98(1).
} 
State is required to surrender a person of that state to the Court." 22 To reconcile the two articles can be, at times, a difficult task, especially when the case before the Court is triggered by a UN Security Council referral. ${ }^{23}$

It is against this background that the discussion of whether Omar Al Bashir was entitled to Head of State immunity has been taking place over the last ten years. Whilst article 27 would render irrelevant any immunity for individuals whose states have ratified the Rome Statute, none of these dispositions does fully encompass Bashir's situation. Sudan has never joined the ICC, which means that it never agreed on the waiver of its sovereign immunities provided for in article 27 . At the same time, the state is being subjected to the jurisdiction of the ICC due to the UN Security Council's referral. ${ }^{24}$ Accordingly, one of the main issues that are in need for clarification is precisely the status of Sudan before the ICC for the purposes of the investigation and subsequent trial of the international crimes that took place in Darfur. ${ }^{25}$

The debate regarding which provision applies to the situation of Bashir, whether article 27(2) or article 98(1), has been a question since the ICC's Pre-Trial Chamber (PTC) I issued the first arrest warrant against $\mathrm{Al}$ Bashir and requested that all member states of the Court arrest and surrender him if/when he visited their territory. The matter presented by this case was whether

22 Rome Statute of the International Criminal Court, article 98(2).

23 TRIFFTERER; BURCHARD. Article 27 Irrelevance of official capacity, p. 1040; For a discussion on the power dynamics established by the UN Security Council's ability to trigger the ICC jurisdiction, see GIANNINI, Luisa; YAMATO, Roberto Vilchez; MARCONI, Claudia Alvarenga, Ruling through the International Criminal Court's rules. Carta Internacional, v. 14, n. 1, p. 177-201, 2019.

24 UNITED NATIONS SECURITY COUNCIL. Resolution 1593 (2005). New York: United Nations Security Council, 2005.

25 For a discussion on the topic, see AKANDE, The Legal Nature of Security Council Referrals to the ICC and its Impact on Al Bashir's Immunities; AKANDE, Who Is Obliged to Arrest Bashir?; GAETA, Does President Al Bashir Enjoy Immunity from Arrest?; OOSTHUIZEN, Gabriël H., Some Preliminary Remarks on the Relationship Between the Envisaged International Criminal Court and the un Security Council, Netherlands International Law Review, v. 46, n. 03, p. 313, 1999; PAPILLON, Has the United Nations Security Council Implicitly Removed Al Bashir's Immunity?; TLADI, D., The ICC Decisions on Chad and Malawi: On Cooperation, Immunities, and Article 98. Journal of International Criminal Justice, v. 11, n. 1, p. 199-221, 2013.; JACOBS, Dov. The Frog that Wanted to Be an Ox: The ICC's Approach to Immunities and Cooperation. In: STAHN, Carsten (org.). The law and practice of the International Criminal Court, First edition. Oxford: Oxford University Press, 2015. p. 281-304. there is an obligation by member states to hand over $\mathrm{Al}$ Bashir to the ICC. In other words, the question is if by not cooperating with the ICC they would be in violation vis-à-vis their contracted obligations as members of the Court.

\subsection{The ICC and AI Bashir's immunity}

The arrest warrants issued by the ICC against $\mathrm{Al}$ Bashir were put to the test from the outset, seeing that many member states received the former Sudanese Head of State in their countries and did not arrest and surrender him to the Court. This situation occurred repeatedly in the past ten years and gave the Court many opportunities to provide a convincing substantiation for its position that Bashir's immunities did not stand before its jurisdiction.

Dealing with a frequent posture by member states of non-compliance with its arrest warrants, the ICC's PTC I determined, in 2011, one of its early rulings in the Al Bashir Case, that Chad and Malawi, when receiving Bashir in their territory, violated their obligations towards the Court. ${ }^{26}$ Even though the PTC I recognised the existence of an inherent tension between articles 27(2) and 98(1) of the Rome Statute, they reasoned that Malawi (and by extension the African Union) would not have any reason to evoke this tension to the matter of immunities of heads of state before international

26 PRE-TRIAL CHAMBER I. Decision pursuant to article 87(7) of the Rome Statute on the refusal of the Republic of Chad to comply with the cooperation requests issued by the Court with respect to the arrest and surrender of Omar Hassan Abmad Al Bashir, The Hague: International Criminal Court (ICC), 2011; PRE-TRIAL CHAMBER I, Corrigendum to the Decision Pursuant to Article 87(7) of the Rome Statute on the Failure by the Republic of Malawi to Comply with the Cooperation Requests Issued by the Court with Respect to the Arrest and Surrender of Omar Hassan Abmad Al Bashir, The Hague: International Criminal Court (ICC), 2011. Before the decision on the obligations of Malawi and Chad to arrest and surrender Bashir to the ICC, the ICC had already issued decisions for Kenya, Chad and Djibouti. Nevertheless, it was only in the decisions on Chad and Malawi that the Court engaged in the task of explaining the existence of an obligation to comply with the ICC's arrest warrants. PRE-TRIAL CHAMBER I, Decision informing the United Nations Security Council and the Assembly of the States Parties to the Rome Statute about Omar Al-Bashir's presence in the territory of the Republic of Kenya, The Hague: International Criminal Court (ICC), 2010; PRE-TRIAL CHAMBER I, Decision informing the United Nations Security Council and the Assembly of the States Parties to the Rome Statute about Omar Al-Bashir's recent visit to the Republic of Chad, The Hague: International Criminal Court (ICC), 2010; PRE-TRIAL CHAMBER I, Decision informing the United Nations Security Council and the Assembly of the States Parties to the Rome Statute about Omar Al-Bashir's recent visit to Djibouti. The Hague: International Criminal Court (ICC), 2011. 
courts. The decision makes use of the Arrest Warrant Judgement to substantiate its argument. However, it does so by employing the same reading of that heavily criticised decision of the SCSL, which is also cited in the PTC I's document. The irrelevance of immunities before an international court, according to the PTC I, was, at that point, already an established practice that can be evidenced from trials such as the ones of Slobodan Milošević (the only one in the list held before the Arrest Warrant Case in the ICJ), Charles Taylor, Muammar Gaddafi, Laurent Gbagbo. This list of cases would serve to prove that "initiating international prosecutions against Heads of State have gained widespread recognition." Hereupon, the Chamber arrives at the conclusion that there is no justification for Malawi to argue in line with article 98(1) and that it must cooperate with the Court's request. ${ }^{27}$ As argued by Robert Cryer, the reasoning in these decisions "is rather thin, and the 'precedents' cited are not directly on point, as they are not about cooperation by domestic authorities, but about the question of immunity as a defence when someone is already before the relevant Court." 28 This position is shared by many who have also deemed the argument "disappointing and unsatisfactory" 29 and even "wrong." 30

The issue of $\mathrm{Al}$ Bashir's immunities was brought back to the attention of the PTC I when he visited the Democratic Republic of the Congo (DRC), in 2014, as a result from the latter's disregard to the warnings from the ICC that, as a member state, it had a duty to arrest and surrender Bashir to the Court. However, as it was noted by many commentators, the argumentation of the PTC I had changed. This decision no longer used

\footnotetext{
27 PRE-TRIAL CHAMBER I. Corrigendum to the Decision Pursuant to Article 87(7) of the Rome Statute on the Failure by the Republic of Malawi to Comply with the Cooperation Requests Issued by the Court with Respect to the Arrest and Surrender of Omar Hassan Ahmad Al Bashir, paras. 36-44. 28 CRYER, Robert. The ICC and its Relationship to Non-States Parties, in: STAHN, Carsten (org.). The law and practice of the International Criminal Court, First edition. Oxford: Oxford University Press, 2015. p. 270

29 TLADI. The ICC Decisions on Chad and Malawi, p. 205.

30 AKANDE, Dapo. ICC Issues Detailed Decision on Bashir's Immunity (. . . At long Last ... ) But Gets the Law Wrong, EJIL: Talk!, Available at: https://www.ejiltalk.org/icc-issues-detailed-decision-on-bashir's-immunity-at-long-last-but-gets-the-law-wrong/. Accessed: 18 Oct. 2020. See also JACOBS, Dov, A Sad Hommage to Antonio Cassese: The ICC's confused pronouncements on State Compliance and Head of State Immunity, Spreading the Jam, Available at: https://dovjacobs.com/2011/12/15/a-sad-hommage-to-antonio-cassese-the-iccs-confused-pronouncements-on-state-compliance-and-head-of-state-immunity/?blogsub=confirming\#blog subscription-2. Accessed: 19 Oct. 2020.
}

the logic of grounding the irrelevance of immunities on customary international law. Instead, it focused on a new reasoning that was rooted in the UN Security Council Resolution 1593. The inexistence of Bashir's immunity before the ICC was no longer a question of a newly established practice but a result from its waiver from the UN Security Council when it decided that Sudan "shall cooperate fully with and provide any necessary assistance to the Court and the Prosecutor pursuant to this resolution." ${ }^{31}$ According to the PTC I, taking into consideration that "immunities attached to Omar $\mathrm{Al}$ Bashir are a procedural bar from prosecution before the Court, the cooperation envisaged in said resolution was meant to eliminate any impediment to the proceedings before the Court, including the lifting of immunities," meaning that with such phrasing the UN Security Council Resolution "implicitly waived the immunities" conferred to Al Bashir under international law. ${ }^{32}$ Furthermore, the PTC I answered to the claims by the DRC and other AU member states that this implicit waiver would trump any obligations they might have had under international law, consequently rendering, according to the PTC I, their eliciting of 98(1) unsuitable for this situation. ${ }^{33}$ This decision marks "a radical shift from the rather prudent position the ICC has so far taken on the lack of cooperation by states parties." ${ }^{\text {34 }}$

In the following year, on June 2015, in maybe one of the most notable moments of $\mathrm{Al}$ Bashir's immunity saga, the then sitting President of Sudan went on an official visit to South Africa for an AU Summit. Whilst he was in the foreign state's territory, it was brought before South African High Court an urgent application that had the goal of having $\mathrm{Al}$ Bashir be arrested and transferred to the ICC. By the time the High Court issued the order that determined so, Al Bashir had managed to flee the country and, hence, was not arrested. ${ }^{35}$

\footnotetext{
31 UNITED NATIONS SECURITY COUNCIL. Resolution 1593 (2005), para. 2

32 PRE-TRIAL CHAMBER I. Decision on the Cooperation of the Democratic Republic of the Congo Regarding Omar Al Bashir's Arrest and Surrender to the Court, The Hague: International Criminal Court (ICC), 2014. para. 29.

33 CRYER. The ICC and its Relationship to Non-States Parties, p. 270.

34 BOSCHIERO, Nerina. The ICC Judicial Finding on Non-cooperation Against the DRC and No Immunity for Al-Bashir Based on UNSC Resolution 1593. Journal of International Criminal Justice, v. 13, n. 3, p. 625-653, 2015. p. 626.

35 MUDUKUTI, Angela. The state of play in the al-Bashir saga. Mail \& Guardian Thought Leader, 2015.
} 
Following this event that gained worldwide attention, after holding hearings and considering submissions from South Africa, the Prosecutor of the ICC, Belgium, and the Southern Africa Litigation Centre (SALC) - the one who filed the urgent application before the High Court -, the PTC II, on 6 July 2017, issued a decision where it rejected South Africa's argument that it had acted lawfully by respecting Bashir's immunities over its ICC obligations and reaffirmed that South Africa had a duty to comply with the ICC's request for the arrest and surrender of Al Bashir. ${ }^{36}$ In this decision, the PTC II's reasoning maintains the theory that it is the UN Security Council Resolution that triggered the jurisdiction of the ICC that removed Al Bashir's immunities once it rendered Sudan in a situation analogous to a member state of the ICC ${ }^{37}$ whilst affirming to be "unable to identify a rule in customary international law that would exclude immunity for Heads of State when their arrest is sought for international crimes by another State, even when the arrest is sought on behalf of an international court, including, specifically, this Court." 38

However, this was the majority's ruling. In his minority opinion, Judge Marc Perrin de Brichambaut took a completely different route from the previous positions of the PTCs in explaining the issue. He signalled his disagreements with the majority decision by reasoning that in the "current state of the law" it is not possible to determine by solely relying on the legal effects of UN Security Council Resolution 1593 that it is either article 27(2) or article 98(1) of the Statute that is applicable between the Court, South Africa and Sudan in the matter of the compliance with the arrest warrants against $\mathrm{Al}$ Bashir. ${ }^{39}$ In this regard, Judge Brichambaut argues that neither hypothesis, the one that considers Sudan in a

\footnotetext{
36 METTRAUX, Guénaël; DUGARD, John; DU PLESSIS, Max. Heads of State Immunities, International Crimes and President Bashir's Visit to South Africa. International Criminal Law Review, v. 18, n. 4, p. 577-622, 2018. p. 580.

37 PRE-TRIAL CHAMBER II. Decision under article 87(7) of the Rome Statute on the non-compliance by South Africa with the request by the Court for the arrest and surrender of Omar Al-Bashir, The Hague: International Criminal Court (ICC), 2017, para 87; DU PLESSIS, Max; TLADI, Dire, The ICC's immunity debate - the need for finality, EJIL: Talk!, Available at: https://www.ejiltalk.org/the-iccs-immunity-debatethe-need-for-finality/. Accessed: 19 Oct. 2020.

38 PRE-TRIAL CHAMBER II. Decision under article 87(7) of the Rome Statute on the non-compliance by South Africa with the request by the Court for the arrest and surrender of Omar Al-Bashir, para. 68.

39 PRE-TRIAL CHAMBER II. Minority Opinion of Judge Marc Perrin de Brichambant, The Hague: International Criminal Court (ICC), 2017. para. 58 .
}

situation analogous to a state party to the Rome Statute or the one that defends that Bashir's immunity was implicitly removed, can be firmly concluded. Moreover, the same is considered towards the argument that posits that it is already customary international law the notion that the involvement of an international court would affect the application of personal immunities. ${ }^{40}$ The Judge inaugurates a line of reasoning stemming from the ICC, the combination of

[A] literal and contextual interpretation of article IV of the Genocide Convention, in conjunction with an assessment of the object and purpose of this treaty, [which can] lead to the conclusion that Omar Al-Bashir does not enjoy personal immunity, having been 'charged' with genocide within the meaning of article VI of the Genocide convention. ${ }^{41}$

The most recent discussion on the issue of Bashir's immunity was in response to another official visit by Bashir - and probably the last, considering that on 11 April 2019 he was removed from office ${ }^{42}$ and is currently under military custody - to attend an Arab League Summit, this time to the Kingdom of Jordan. The PTC II, on 11 December 2017, released its finding of non-compliance with the ICC's request to arrest and surrender Bashir. This decision maintained the majority's contention from the previous finding that Bashir is not entitled to immunities due Security Council Resolution 1593's imposition of the duties and obligations of the Rome Statute to Sudan, rendering it in a position analogous of a state party. It, again, reaffirmed that Jordan, as a member state of the ICC, violated its obligations towards the Court. ${ }^{43}$ Notwithstanding, Jordan appealed this decision, ${ }^{44}$ a move that opened the space for further

40 PRE-TRIAL CHAMBER II. Minority Opinion of Judge Marc Perrin de Brichambaut, ICC-02/05-01/09-302-Anx, The Hague: International Criminal Court (ICC), 2017. para. 99.

${ }^{41}$ PRE-TRIAL CHAMBER II. Minority Opinion of Judge Marc Perrin de Brichambaut, ICC-02/05-01/09-302-Anx, The Hague: International Criminal Court (ICC), 2017. para. 100.

42 Sudan crisis: Ex-President Omar al-Bashir moved to prison, $B B C$ News, 2019.

43 PRE-TRIAL CHAMBER II. Decision under article 87(7) of the Rome Statute on the non-compliance by Jordan with the request by the Court for the arrest and surrender or Omar Al-Bashir, The Hague: International Criminal Court (ICC), 2017, para. 44. In light of this decision, again, Judge Brichambaut manifested his disagreement with the line of reason of the majority of PTC II and sustained his argument for a removal of Bashir's immunity grounded on the Genocide Convention on a minority opinion. PRE-TRIAL CHAMBER II, Minority Opinion of Judge Marc Perrin de Brichambaut, The Hague: International Criminal Court (ICC), 2017.

44 APPEALS CHAMBER. The Hashemite Kingdom of Jordan's appeal against the "Decision under article 87(7) of the Rome Statute on the non- 
discussions after four conflicting decisions by the chambers of the ICC on the matter of Bashir's immunities before the Court. ${ }^{45}$

\subsection{The Appeals Chamber Judgment on the non-compliance by Jordan with the request by the Court for the arrest and surrender of Bashir}

For the first time, the issue of whether Bashir's immunity would preclude him from proceedings before the ICC was to be before the Appeals Chamber (AC) of the ICC. From the beginning, the AC seemed to be taking a completely different approach from the PTCs. In the face of several controversies facing this case, the international law community, in general, welcomed the AC's decision to invite legal scholars to elaborate submissions in order to assist the Court in putting an end to this long-lasted debate that has been for the ICC a thorn in its side. This was the first time the ICC invited a large number of submissions by legal scholars, a move that resembled the practice of ad hoc tribunals, such as the ICTY and SCSL. ${ }^{46}$

The decision of the AC demarcated the invitation to states parties and "Professors of International Law," who would request leave to submit their observations and some would be appointed amicus curiae. ${ }^{48}$ There was a total of 11 observations as amicus curiae by scholars out of the 17 requests, besides submissions by the African Union and the League of Arab States and reactions to all these observations by Jordan and the Prosecution. ${ }^{49}$

compliance by Jordan with the request by the Court for the arrest and surrender [of] Omar Al-Bashir", The Hague: International Criminal Court (ICC), 2018.

45 AKANDE, Dapo. The Bashir Appeal at the ICC, EJIL: Talk!, Available at: https://www.ejiltalk.org/the-bashir-appeal-at-the-icc/. Accessed: 19 Oct. 2020.

$46 \mathrm{MAO}$, Xiao, The Function of Amicus Curiae Participation by Legal Scholars: The Al-Bashir Appeal Case at the International Criminal Court as an Illustration, Chinese Journal of International Law, v. 18, n. 2, p. 393-424, 2019, p. 394.

47 APPEALS CHAMBER. Order inviting expressions of interest as amici curiae in judicial proceedings (pursuant to rule 103 of the Rules of Procedure and Evidence), The Hague: International Criminal Court (ICC), 2018. para. 4.

48 NOUWEN, Sarah M.H., RETURN TO SENDER: LET THE INTERNATIONAL COURT OF JUSTICE JUSTIFY OR QUALIFY INTERNATIONAL-CRIMINAL-COURT EXCEPTIONALISM REGARDING PERSONAL IMMUNITIES, The Cambridge Law Journal, v. 78, n. 3, p. 596-611, 2019, p. 603.

49 The list of requests and submissions can be found through the ICC's website research tool: https://www.icc-cpi.int/Pages/search-
The result was dozens of legal opinions and a week of spectacular hearings, streamed online, in which in addition to the strong teams representing Jordan, the African Union, and the League of Arab States, 16 law professors, including the crème de la crème of the field, gave their (widely diverging) views on the questions presented to them. ${ }^{50}$

The AC gave its decision on Jordan's appeal on 6 May 2019. Through a line of reasoning that surprised many observers of the Court, the AC gave its final statement on the issue of Jordan's non-compliance with the ICC's arrest warrants by returning to the arguments sustained in the Malawi decision. ${ }^{51}$ The Chamber was unanimous in asserting that "Jordan had failed to comply with its obligations under the Statute by not executing the Court's request for the arrest of $\mathrm{Mr}$ Al-Bashir and his surrender to the Court while he was on Jordanian territory." 52 On the matter of the position of Sudan before the ICC, it considered that UN Security Council Resolution left the country in an analogous condition to that of a state party, ${ }^{53}$ sticking to the idea of the horizontal effect of the Security Council referral and dropping the argument of the implicit waiver of immunity.

The AC concluded that " $\mathrm{t}]$ here is neither State practice nor opinio juris that would support the existence of Head of State immunity under customary international law vis-à-vis an international court." The Chamber verified the opposite. There has never existed a customary international law that established that such immunities would serve as an impediment to the exercise of jurisdiction of an international court. ${ }^{54}$ Furthermore, the Chamber adds that this finding also serves the purpose

results.aspx

50 NOUWEN, RETURN TO SENDER, p. 603-604.

51 KJELDGAARD-PEDERSEN. Is the Quality of the ICC's Legal Reasoning an Obstacle to Its Ability to Deter International Crimes? 52 APPEALS CHAMBER. Judgment in the Jordan Referral re Al-Bashir Appeal, The Hague: International Criminal Court (ICC), 2019, para. 215. Nevertheless, the AC ruled by majority on the issue of the referral to the Assembly of States Parties and UN Security Council, deeming the decision of the PTC erroneous. For more on this issue, see MUDUKUTI, Angela, Prosecutor v. Omar Hassan Ahmad Al-Bashir, Judgment in the Jordan Referral re Al-Bashir Appeal, American Journal of International Law, v. 114, n. 1, p. 103-109, 2020; WEATHERALL, Thomas, Prosecutor v. Omar Al-Bashir, Judgment in the Jordan Referral Re Al-Bashir Appeal (Int'L Crim. Ct.), International Legal Materials, v. 58, n. 6, p. 1177-1233, 2019; APPEALS CHAMBER, Judgment in the Jordan Referral re Al-Bashir Appeal. 53 MUDUKUTI, Prosecutor v. Omar Hassan Ahmad Al-Bashir, Judgment in the Jordan Referral re Al-Bashir Appeal, p. 105.

54 APPEALS CHAMBER. Judgment in the Jordan Referral re Al-Bashir Appeal, para. 1. 
of covering the horizontal relationship between states when the request to arrest and surrender is made by an international court ${ }^{55}$ which leaves no margin for interpreting Article 27(2) in a way that allows a state party to invoke immunities "in the horizontal relationship if the Court were to ask for the arrest and surrender of the Head of State by making a request to that effect to another State Party." 56

Regardless of the very open approach of receiving outside submissions to improve the debate and help in finding a solution for the matter at hand before reaching a decision, the $\mathrm{AC}$ ruling faced severe criticism ${ }^{57}$ for repeating previous positions of the PTC, for continuously dismissing member states' arguments, and mostly for its somewhat incoherent treatment of customary international law. ${ }^{58}$

\subsection{Developments in reaction to the ICC's rulings on Bashir's immunity}

This position of the ICC of not engaging or even dismissing member states' and other actor's arguments and requests has been a widely worked topic ${ }^{59}$ and can be quite damaging for the Court, considering that its rejection of a productive engagement creates the space for some unfounded critiques and contestation to receive more credit than they are due. Some member states

55 APPEALS CHAMBER. Judgment in the Jordan Referral re Al-Basbir Appeal, para. 2.

56 APPEALS CHAMBER. Judgment in the Jordan Referral re Al-Bashir Appeal, para. 4.

57 For the critiques on the AC's decision of 6 May 2019, see AKANDE, Dapo, ICC Appeals Chamber Holds that Heads of State Have No Immunity Under Customary International Law Before International Tribunals, EJIL: Talk!, Available at: https:// www.ejiltalk.org/icc-appeals-chamber-holds-that-heads-of-statehave-no-immunity-under-customary-international-law-before-international-tribunals/. Accessed: 19 Oct. 2020; JACOBS, Dov, You have just entered Narnia: ICC Appeals Chamber adopts the worst possible solution on immunities in the Bashir case, Spreading the Jam, Available at: https://dovjacobs.com/2019/05/06/you-have-justentered-narnia-icc-appeals-chamber-adopts-the-worst-possible-solution-on-immunities-in-the-bashir-case/. Accessed: 19 Oct. 2020; BATROS, Ben, A Confusing ICC Appeals Judgment on Head of State Immunity, Just Security, Available at: https://www.justsecurity. org/63962/a-confusing-icc-appeals-judgment-on-head-of-state-immunity/. Accessed: 19 Oct. 2020.

58 KJELDGAARD-PEDERSEN. Is the Quality of the ICC's Legal Reasoning an Obstacle to Its Ability to Deter International Crimes? 59 See, for example, NOUWEN, S. M. H.; WERNER, W. G., Doing Justice to the Political: The International Criminal Court in Uganda and Sudan. European Journal of International Law, v. 21, n. 4, p. 941$965,2010$. have been from a long time requesting that the chambers of the Court give a clear explanation on the relationship between articles 27(2) and 98(1) and, as seen in the listed criticisms to both the PTCs' and AC's rulings, so far, no decision has given a satisfactory elucidation. This dissatisfaction has been voiced by several African states, which have joined forces under the scope of the African Union (AU) in order to present a united front before the ICC.

Throughout the years, these African states have made different kinds of requests to the ICC and the UN Security Council that range from demands for clarification regarding the interpretation of specific norms to solicitations to the Court to suspend the case against Bashir. Most of those pleas, regardless of whether they have a grounding or not, were never even heard by any of those institutions. ${ }^{60}$ For the purposes of this article, we are engaging only with the oppositions voiced concerning the $\mathrm{Al}$ Bashir Case and its ramifications. Nevertheless, it is essential to note that the position of the AU does not mean a general alignment contrary to any trial against African leaders. The regional organization does not stand as opposition in situations where the state has waived its immunities, allowing the Court to have jurisdiction over its nationals, be it a high-ranking official or not, as was the case with the situations of the DRC, the Central African Republic (CAR), Uganda and the Ivory Coast in the ICC. In general, these countries are opposed to processes against sitting heads of state, ${ }^{61}$ something that was made clear in the drafting of the Malabo Protocol, in particular in cases referred by the Security Council, for it involves states not parties to the Court.

Since the PTC I released the arrest warrants against Bashir, there has been a constant demonstration from member states, more specifically AU members, and also some countries of the League of Arab Nations, stating that they disagree with the legal reasoning stemming from the ICC's chambers. Asserting that they could no longer remain in the Court due to conflicting obligations, some states took their grievances one step ahead and announced their denunciation of the Rome Statute. jurisdiction-some-recent-developments/. Accessed: 19 Oct. 2020. 
The first move was made by South Africa, on 21 June 2016, by delivering an official communication declaring its withdrawal. However, the notice was later retreated because, in a domestic process, it was considered that it did not fulfil the necessary rites for denouncing a treaty. ${ }^{62}$ Soon after South Africa delivered its notification, Burundi followed suit, but it did so after having a vote in its parliament getting 94 positive votes out of the 110 members of parliament. Still, in the same year, the Gambia publicly stated its intention leave the ICC and even sent its notification but rescinded it later. Even though there is a general argument justifying these withdrawals, the precise trigger for these departures remains not known. ${ }^{63}$

After being delayed a couple of times, on 31 January 2017, in the AU summit, its member states developed a "Withdrawal Strategy" ${ }^{\prime 4}$ something that had been in the talks for some time. This strategy for withdrawal is "purposefully weak," considering the adopted vocabulary, and had many reservations to its text - either to the entire project or to some of its paragraphs. Mark Kersten posits that this document does not even make a call for a mass withdrawal of states from the ICC and, in this sense, should be read more as a "reasonable list of possible reforms to the Rome Statute and to the Court [...] [that] should be taken seriously and continue to be debated," than a pledge for denouncing the Rome Statute. ${ }^{65}$

In the following year, the $\mathrm{AU}$ summit came up with another policy towards the ICC. This time, its proposal had a very constructive tone. The AU announced that "it would seek, through the UN General Assembly, an advisory opinion from the International Court of Justice (ICJ) on the question of immunity," ${ }^{66}$ a proposal

${ }_{62}$ For more on South Africa and its decision to remain or not on the ICC, see PILLAY, Navi; GOLDSTONE, Richard; KERSTEN, Mark, A Graceful Exit for South Africa's ICC Withdrawal Plans, Justice in Conflict, Available at: https://justiceinconflict.org/2018/09/10/a-gracefulexit-for-south-africas-icc-withdrawal-plans/. Accessed: 19 Oct. 2020.

63 LABUDA, Patryk I. The African Union's Collective Withdrawal from the ICC: Does Bad Law make for Good Politics?, EJIL: Talk!, Available at: https://www.ejiltalk.org/the-african-unions-collectivewithdrawal-from-the-icc-does-bad-law-make-for-good-politics/. Accessed: 19 Oct. 2020.

64 AFRICAN UNION (AU). Withdrawal Strategy Document, Addis Ababa: African Union (AU), 2017.

${ }^{65}$ KERSTEN, Mark. Not All it's Cracked Up to Be - The African Union's "ICC Withdrawal Strategy", Justice in Conflict, Available at: https://justiceinconflict.org/2017/02/06/not-all-its-crackedup-to-be-the-african-unions-icc-withdrawal-strategy/. Accessed: 19 Oct. 2020.

66 REINOLD, Theresa. African Union v International Criminal that had been mentioned years before in the AU 2012 summit. ${ }^{67}$ The same summit also decided to propose a declaratory/interpretive clarification from the ICC Assembly of States Parties on the relationship between articles 27 and $98 .{ }^{68}$

The relationship of the Court with states and organisations have resulted in fiery conflicts due to the very nature of the object of discussion, which is their duties and obligations. Nevertheless, legal scholars and practitioners, as can be seen by some excerpts in the previous section, also have shared their discontentment towards the positions adopted by the Court and were 'attacked' for doing so, a reaction that clearly shows that, even though the ICC presents itself as an open institution, inviting observations and comments on its current proceedings, it still has trouble dealing with the criticism it receives.

An episode that paints this picture very well took place in the days following the AC's ruling on Jordan's non-compliance. Given the amount of scrutiny and disapproving comments regarding this decision, it was posted on the ICC's website a Q\&A on the AC's 6 May 2019 Judgement that besides repeating the Chamber's arguments (and making a confusion regarding some points while doing $\left.\mathrm{sO}^{69}\right)$, launches an attack on the critics of the "blogosphere," which we might add is a group composed by some of the most esteemed international criminal law professors. The text reads:

In the era of social media, it is hoped that obser-
vers would properly study the Court's judgments
and decisions before rushing to comment on them.
Hastily made comments, particularly when made
before the commentator has even read the judg-
ment in question, will fail to appreciate the totali-
ty and nuances of the Court's reasoning, and may
wholly misrepresent the decision or judgment. At
the same time, those first comments appearing on

Court: episode MLXIII (?), EJIL: Talk!, Available at: https://www. ejiltalk.org/african-union-v-international-criminal-court-episodemlxiii/. Accessed: 19 Oct. 2020.

${ }^{67}$ AKANDE, Dapo. The African Union's Response to the ICC's Decisions on Bashir's Immunity: Will the ICJ Get Another Immunity Case?, EJIL: Talk!, Available at: https://www.ejiltalk.org/theafrican-unions-response-to-the-iccs-decisions-on-bashirs-immunity-will-the-icj-get-another-immunity-case/. Accessed: 19 Oct. 2020.

68 AFRICAN UNION (AU). Decision on the International Criminal Court, Addis Ababa: [s.n.], 2018.

69 In its discussion, the Q\&A comes back to the argument that the ICJ's Arrest Warrant Case is a defining pronouncement on the inexistence of immunities before international criminal courts. An interpretation that has been repeatedly reaffirmed by scholars in the field to be misleading. On these confusions furthered by the Q\&A, see NOUWEN, RETURN TO SENDER, p. 609. 
social media frequently tend to dominate the ensuing discussion as they are tweeted and retweeted, regardless of their accuracy.

Lawyers engaging in public commentary should exercise particular caution and remain mindful of the cardinal principles that guide the conduct of lawyers, including that of honesty, integrity and fairness. This principle adequately covers the need to be fair when criticising courts and judges. Notably, the rules of professional ethics in most legal systems impose special caution on criticism of judges and courts, not because it is wrong to criticise them, but because they are generally not in a position to respond to specific criticisms. It does not mean that judges and courts may not be criticised. It only means that they be criticised fairly. There is an ethical obligation to reflect facts and circumstances accurately and fairly. It is not enough to engage in convenient repeat of the commentaries of others, who may not have been fair to begin with. ${ }^{70}$

This very defensive reaction of the Court ${ }^{71}$ in this anonymous Q\&A does no good to the already damaged perception of the Court. Besides deeming itself as the authority into what counts as good criticism, there is a "lack of self-reflection" by the Court "coupled with a disdain for those who disagreed with the decision," phrasing it in a way that almost states that whoever did not agree with the decision, did so because they did not understand. ${ }^{72}$ If the procedural and legal issues were not matters of divergence enough, with this document, the Court puts itself in a position that it might not be able to afford.

\section{The rulings from the ICC and the different forms of contestation}

There are different ways of engaging in actions of contestation concerning international courts and, in the recent years, in respect to a wide variety of courts, there

\footnotetext{
70 Question and Answers - Q $A$ REG ARDING APPE ALS CHAMBER'S 6 MAY 2019 JUDGMENT IN THE JORDAN REFERRAL RE AL-BASHIR APPEAL, International Criminal Court (ICC), Available at: https://www.icc-cpi.int/itemsDocuments/190515-albashir-qa-eng.pdf. Accessed: 19 Oct. 2020.

71 Since it was not made public which organ of the ICC published the document, we will reference it as the Court.

${ }^{72}$ JACOBS, Dov, Q\&A regarding the "Q\&A REGARDING APPEALS CHAMBER'S 6 MAY 2019 JUDGMENT IN THE JORDAN REFERRAL RE AL-BASHIR APPEAL", Spreading the Jam, Available at: https://dovjacobs.com/2019/05/17/qa-regardingthe-qa-regarding-appeals-chambers-6-may-2019-judgment-in-thejordan-referral-re-al-bashir-appeal/. Accessed: 19 Oct. 2020.
}

has been intense growth in the practices of contestation that are directed at them. ${ }^{73}$ With a careful look at the different engagements with the ICC by external actors, it is possible to identify different contestation practices. For what is envisaged by this article, it is vital to be able to differentiate between certain forms of contestation so that we can evaluate what triggered them.

The way that actors outside the ICC react to its rulings or other decisions regarding immunities, as seen, has ranged from warnings of intent to withdraw (or even actual withdrawal) to requests for further clarification of specific legal definitions and redaction of legal arguments. Even though there is a wide array of possible responses that challenge the Court, they do not have the same intent or reason for action. In general, these practices of contestation can take two forms: the ones that engage with a specific case law attempting to have any sort of influence over it; and those that are of a more abnormal kind that are not part of the regular process of international law. Each form of contestation has a different intention, whilst the first takes place considering all the workings and constraints of the system, the last manoeuvres through these limitations seeking to overturn this system. ${ }^{74}$

Actions such as participating in a debate on the legal underpinnings that sustain the (in)existence of a right to claim immunity by Bashir, redacting a scholarly piece to substantiate an interpretation regarding the applicability of personal immunities in cases before of international courts or other ways of presenting a particular view on a conflict between two rules in force, are all part of the ordinary kind of contestation. Within this category are the frequent disagreements and disputes over the content, application and interpretation of a legal rule, a necessary process in a wholesome dynamic. In this sense, this kind of contestation is a constant process in the field of international law. It can have different degrees, being either a dispute over the interpretation of a single norm or a challenge to an entire body of law. This pattern of contestation can be characterised as pushba$c k$, and it takes place in legal journals, professional and institutional meetings, public and political discussions,

\footnotetext{
KRISCH, Nico, The Backlash against International Courts, Völkerrechtsblog, Available at: https://voelkerrechtsblog.org/articles/ the-backlash-against-international-courts/. Accessed: 19 Oct. 2020. 74 MADSEN; CEBULAK; WIEBUSCH, Backlash against international courts, p. 202-203.
} 
among others. ${ }^{75}$ In the events narrated in the previous sections, such type of contestation could be seen taking place when the AC opens the space and invite academics and actors from the political field like international organisations to present their different arguments on the matter, in discussions being held at the ICC's ASP and also with the vast array of academic commentary to the Court's rulings.

Notwithstanding, there is another kind of possible reactions to international courts. Backlash would be the form of contestation which is extraordinary. Whilst the other pattern of contestation is making a direct engagement with the law, this one targets the institution and its authority and tries to undermine it. The goal with this type of action is to have a more profound impact of changing or shutting an international court. Differently from the case of pushbacks that can be triggered by a decision on a legal case, this form of contestation is the choice in situations of considerable social and political inequalities that require extraordinary measures to fix it. ${ }^{76}$ This form of contestation is usually undertaken by a group of actors. Amongst this type of actions, then, would be the ones that get to a more extreme nature like consistent non-compliance and (the threat of) withdrawals as one of its last resorts. The very case that is the central object of analysis of the current piece takes place due to a sequence of practices of backlash. It may be argued that in the beginning it did not consist of a deliberated effort by these actors. Even though they were actions associated with this second category of contestation, the states engaging in practices of non-compliance did so because they had a particular interpretation regarding the matters of the Case, not the work of the institution.

Hereupon, it is also possible to see how measures that are more frequently associated as practices of pushback can become something more extensive if the Court does not deal with them appropriately. As for the matter at hand, this process can be seen regarding the different groups of actors in the field of international criminal law. As seen, states were the ones that took the

\footnotetext{
75 MADSEN, Mikael Rask; CEBULAK, Pola; WIEBUSCH, Micha. Backlash against international courts: explaining the forms and patterns of resistance to international courts. International Journal of Law in Context, v. 14, n. 2, p. 197-220, 2018. p. 202-203.

76 MADSEN, Mikael Rask; CEBULAK, Pola; WIEBUSCH, Micha. Backlash against international courts: explaining the forms and patterns of resistance to international courts. International Journal of Law in Context, v. 14, n. 2, p. 197-220, 2018. p. 202-203.
}

responses of the ICC harder and for quite a while transformed their lonesome initiatives into a concerted endeavour that sought to call the attention of the Court.

By analysing the $\mathrm{Al}$ Bashir Case in the ICC through these concepts of backlash and pushback, it is possible to establish a correlation between each type of contestation and the action of the Court that triggered it. When the Chambers of the ICC seek explanations from member states for their non-compliance with its arrest warrants and opens the Court to host discussions over a problematic issue in a case, even though there is still contestation - for it is the ordinary process of the law it is the welcomed kind. The Court should expect actors to engage in practices of pushback and not take it in the wrong way. This demonstrates the willingness of these actors to find, by positing the different interpretations, a common ground with the Court in a way to solve the disputed matter. The option of not engaging with the arguments coming from outside the court when giving its rulings, by placing itself as the final authority on the matter and having reactions such as the one seen in the Q\&A, however, mobilise these actors to engage in the forms of contestation that a Court should not want. Backlashes are the type of contestation triggered by perceptions that there is more chance of engaging in fruitful discussions. It is the reaction of those who no longer believe that the Court is still able to achieve its purposes. Moreover, it is possible to find such arguments concerning the ICC.

In this sense, the Court should consider that the practices of contestation that surround its workings are triggered by the very postures that it chooses to assume. The defensive way the ICC has worked in ruling the issue of Bashir's immunities has triggered both actions of pushback and backlashes, and the latter has gained a fairground. The result in that its authority and legitimacy have been negatively impacted, chaining processes that undermine the realisation of its very purpose: international justice.

\section{Conclusion}

From the presentation of the events pertaining to the Al Bashir Case in the ICC, we can notice that throughout the last ten years the contestations against the Court have taken more massive proportions. The cons- 
tant shifting of rationale in the rulings and the lack of engagement by them with the issues posed by the actors had the effect of fraying and wearing an already complicated relationship. Moreover, as acknowledged by many authors, it is not only concerning African states but a broader group that includes not only other states but also organisations and other categories of actors of the international criminal law community.

This dynamic which was a constant throughout the Al Bashir Case seemed to have reached a peak with the ruling of the AC on Jordan's non-cooperation with arresting and surrendering Bashir to the Court. In spite the fact that both Court and external actors expected to have some closure in the issue of heads of state immunity before international criminal courts, finally giving a decisive answer to the Court's rationale for purporting its position that Bashir is not entitled to immunities concerning this case, the result was the opposite. By making the grand gesture of proposing a debate with the key figures of the field of international criminal law, the AC had signalled its openness to traverse uncharted waters taking into consideration the different possibilities of analysing the (in) existence of Bashir's immunity. However, what came out of this situation was that the Court perceives "itself as 'an international court acting on behalf of the international community' with powers [to] override customary rules on immunities accruing to senior officials of third States" ${ }^{\text {77 }}$ and has no willingness to inaugurate or participate in a more meaningful debate that accommodates pushbacks as a wholesome and very much an intrinsic part of international law.

Per the analysis of the contestation in the $\mathrm{Al} \mathrm{Bashir}$ Case, it was possible to recognise that these practices of pushback, when not met halfway, tend to be short-lived and quickly escalate towards a backlash that is way more detrimental to any international court than the alternative, which is engaging with the constructive kind of criticism. Since the ICC has chosen to take the most challenging path, it now faces a very delicate moment in its history dealing with practices of backlash that extrapolate the situation narrated and analysed in this piece.

As for the Al Bashir Case, it is still open whether we will see much closure. Since he was ousted from power in 2019, there have been reports that the current gover-

KJELDGAARD-PEDERSEN. Is the Quality of the ICC's Legal Reasoning an Obstacle to Its Ability to Deter International Crimes? nment of Sudan would allow the ICC to try Bashir. ${ }^{78}$ Nevertheless, whether this will take place or not has little significance to the international law of immunities. Notwithstanding, we can retrieve an opportunity out of this situation, which is to make a debate that became all about Bashir be turned into a discussion on the relationship between articles 27 and 98 of the Rome Statute, customary international law and the UN Security Council per se. This can improve the quality of this dialogue significantly since it will no longer bear the burden of being associated with defending or "protecting evil., 79

Another implication of Bashir no longer being in office is that we do not know whether the AU is still interested in seeking an opinion from the ICJ. The Advisory Opinion can still be an excellent chance to have the ICJ delve further into its affirmation, explaining "what exactly it meant when it suggested that the ordinarily applicable international law on immunities need not be an obstacle 'before certain international criminal courts, where they have jurisdiction," that has been already used by two international criminal courts (and, for that matter, of different natures ${ }^{80}$ ) that "have built a structure of case law on this one obiter comment, which it seems unable to support." $\$ 1$

${ }_{78}$ Although many jumped to the conclusion that Bashir would be sent by Sudan to The Hague to stand trial, it was never totally clear what the government of Sudan meant by having him "appear" before the ICC. While some even contemplated that the government meant having a trial in loco, we need to wait and see what the next steps will be. For more on this topic, see DEFALCO, Randle, Sudan Announces Intention to Send al-Bashir to the ICC (Kind of), Just Security, Available at: https://www.justsecurity.org/68643/ sudan-announces-intention-to-have-al-bashir-and-others-appearbefore-the-icc/. Accessed: 20 Oct. 2020; KERSTEN, Mark, Sudan's Omar al-Bashir may finally face justice for Darfur. But the work is not yet done, Justice in Conflict, Available at: https://justiceinconflict. org/2020/02/21/sudans-omar-al-bashir-may-finally-face-justicefor-darfur-but-the-work-is-not-yet-done/. Accessed: 20 Oct. 2020.

79 TLADI, Dire. Sudan Agrees to Send Al Bashir to the ICC: What Now for the Law?, Opinio Juris, Available at: http://opiniojuris. org/2020/02/12/sudan-agrees-to-send-al-bashir-to-the-icc-whatnow-for-the-law/. Accessed: 20 Oct. 2020.

80 While both were established by treaties, the ICC has universal membership in the sense that any state can join and be subjected to its jurisdiction while the SCSL originated from a bilateral agreement between the UN and the government of Sierra Leone.

${ }^{81}$ NOUWEN, RETURN TO SENDER. For an argument against the idea of requesting and Advisory Opinion for the ICJ on the matter of immunities, see HAQUE, Adil Ahmad, Head of State Immunity is Too Important for the International Court, Just Security, Available at: https://www.justsecurity.org/68801/head-of-stateimmunity-is-too-important-for-the-international-court-of-justice/. Accessed: 20 Oct. 2020. 
This means we believe that a positive undertaking by the ICC and the external actors that navigate on the field of international criminal law would be not to stop the processes which are currently in progress. Keeping the discussion on immunities before international criminal tribunals and maintaining the goal of having the ICJ issue an opinion on the topic can be very fruitful and also help to have matters clear in case it arises in a new situation. For the ICC, this can also be an important demonstration of its commitment and help mend the broken relationship it has with some states, organisations and even scholars.

\section{References}

AFRICAN UNION (AU). Decision on the International Criminal Court. Addis Ababa: [s.n.], 2018.

AFRICAN UNION (AU). Withdrawal Strategy Document. Addis Ababa: African Union (AU), 2017.

AKANDE, D. The Legal Nature of Security Council Referrals to the ICC and its Impact on Al Bashir's Immunities. Journal of International Criminal Justice, v. 7, n. 2, p. 333-352, 2009.

AKANDE, Dapo. ICC Appeals Chamber Holds that Heads of State Have No Immunity Under Customary International Law Before International Tribunals. EJIL: Talk! Available at: https://www.ejiltalk.org/icc-appealschamber-holds-that-heads-of-state-have-no-immunityunder-customary-international-law-before-international-tribunals/. Accessed: 19 Oct. 2020.

AKANDE, Dapo. ICC Issues Detailed Decision on Bashir's Immunity (. . . At long Last . . . ) But Gets the Law Wrong. EJIL: Talk! Available at: https://www.ejiltalk.org/icc-issues-detailed-decision-on-bashir's-immunity-at-long-last-but-gets-the-law-wrong/. Accessed: 18 oct. 2020.

AKANDE, Dapo. The African Union, the ICC and Universal Jurisdiction: Some Recent Developments. EJIL: Talk! Available at: https://www.ejiltalk.org/theafrican-union-the-icc-and-universal-jurisdiction-somerecent-developments/. Accessed: 19 Oct. 2020.

AKANDE, Dapo. The African Union's Response to the ICC's Decisions on Bashir's Immunity: Will the ICJ Get Another Immunity Case? EJIL: Talk! Available at: https://www.ejiltalk.org/the-african-unions-response- to-the-iccs-decisions-on-bashirs-immunity-will-the-icjget-another-immunity-case/. Accessed: 19 Oct. 2020.

AKANDE, Dapo. The Bashir Appeal at the ICC. EJIL: Talk! Available at: https://www.ejiltalk.org/the-bashirappeal-at-the-icc/. Accessed: 19 Oct. 2020.

AKANDE, Dapo. The Immunity of Heads of States of Nonparties in the Early Years of the ICC. AJIL Unbound, v. 112, p. 172-176, 2018.

AKANDE, Dapo. Who Is Obliged to Arrest Bashir? EJIL: Talk! Available at: http://www.ejiltalk.org/theafrican-union-the-icc-and-universal-jurisdiction-somerecent-developments/. Accessed: 5 Aug. 2020.

ALMEIDA, Paula Wojcikiewicz. Imunidades jurisdicionais do Estado perante a Corte Internacional de Justiça:uma análise a partir do caso Alemanha vs. Itália. Revista Direito GV, v. 12, n. 2, p. 516-541, 2016.

APPEALS CHAMBER. Judgment in the Jordan Referral re Al-Bashir Appeal. The Hague: International Criminal Court (ICC), 2019.

APPEALS CHAMBER. Order inviting expressions of interest as amici curiae in judicial proceedings (pursuant to rule 103 of the Rules of Procedure and Evidence). The Hague: International Criminal Court (ICC), 2018.

APPEALS CHAMBER. Prosecutor v. Taylor, Decision on Immunity from Jurisdiction. Freetown: Special Court for Sierra Leone (SCSL), 2004.

APPEALS CHAMBER. Prosecutor v. Tihomir Blaskic, Judgement on the Request of the Republic of Croatia for Review of the Decision of Trial Chamber II of 18 July 1997. The Hague: International Criminal Tribunal for the former Yugoslavia (ICTY), 1997.

APPEALS CHAMBER. The Hashemite Kingdom of Jordan's appeal against the 'Decision under article 87(7) of the Rome Statute on the non-compliance by Jordan with the request by the Court for the arrest and surrender [of] Omar Al-Bashir". The Hague: International Criminal Court (ICC), 2018.

BASSIOUNI, M. Cherif. UNIVERSAL JURISDICTION UNREVISITED: THE INTERNATIONAL COURT OF JUSTICE DECISION IN CASE CONCERNING THE ARREST WARRANT OF 11 APRIL 2000 (DEMOCRATIC REPUBLIC OF THE CONGO V BELGIUM). The Palestine Yearbook of International Law, v. 12, n. 1, p. 27-48, 2002. 
BATROS, Ben. A Confusing ICC Appeals Judgment on Head of State Immunity. Just Security. Available at: https:/ /www.justsecurity.org/63962/a-confusing-iccappeals-judgment-on-head-of-state-immunity/. Accessed: 19 Oct. 2020.

BOISTER, N. The ICJ in the Belgian Arrest Warrant Case: Arresting the Development of International Criminal Law. Journal of Conflict and Security Law, v. 7, n. 2, p. 293-314, 2002.

BOSCHIERO, Nerina. The ICC Judicial Finding on Non-cooperation Against the DRC and No Immunity for Al-Bashir Based on UNSC Resolution 1593. Journal of International Criminal Justice, v. 13, n. 3, p. 625-653, 2015.

CRYER, Robert. Prosecuting the Leaders: Promises, Politics and Practicalities. Goettingen Journal of International Law, 2009.

CRYER, Robert. The ICC and its Relationship to NonStates Parties. In: STAHN, Carsten (org.). The law and practice of the International Criminal Court. Oxford: Oxford University Press, 2015. p. 260-280.

DEFALCO, Randle. Sudan Announces Intention to Send al-Bashir to the ICC (Kind of). Just Security. Available at: https://www.justsecurity.org/68643/sudanannounces-intention-to-have-al-bashir-and-others-appear-before-the-icc/. Accessed: 20 Oct. 2020.

DU PLESSIS, Max; TLADI, Dire. The ICC's immunity debate - the need for finality. EJIL: Talk! Available at: https://www.ejiltalk.org/the-iccs-immunity-debatethe-need-for-finality/. Accessed: 19 Oct. 2020.

GAETA, P. Does President Al Bashir Enjoy Immunity from Arrest? Journal of International Criminal Justice, v. 7, n. 2, p. 315-332, 2009.

GIANNINI, Luisa; YAMATO, Roberto Vilchez; MARCONI, Claudia Alvarenga. Ruling through the International Criminal Court's rules. Carta Internacional, v. 14, n. 1, p. 177-201, 2019.

GONZÁLEZ-RUIZ, Cristián D.; MIJARES, Víctor M. Los fuertes hacen lo que quieren: exponiendo los límites de la Corte Penal Internacional. Revista de Direito Internacional, v. 17, n. 1, 2020.

HAQUE, Adil Ahmad. Head of State Immunity is Too Important for the International Court. Just Security. Available at: https://www.justsecurity.org/68801/head-of- state-immunity-is-too-important-for-the-internationalcourt-of-justice/. Accessed: 20 Oct. 2020.

INTERNATIONAL COURT OF JUSTICE (ICJ). Jurisdictional Immunities of the State (Germany v. Italy: Greece intervening). The Hague. 2012. (I.C.J. Reports 2012).

INTERNATIONAL COURT OF JUSTICE (ICJ). $A r$ rest Warrant of 11 April 2000 (Democratic Republic of the Congo v. Belgium). The Hague: International Court of Justice (ICJ), 2002. (I.C.J. Reports 2002).

JACOBS, Dov. A Sad Hommage to Antonio Cassese: The ICC's confused pronouncements on State Compliance and Head of State Immunity. Spreading the Jam. Available at: https://dovjacobs.com/2011/12/15/a-sad-hommage-to-antonio-cassese-the-iccs-confused-pronouncements-on-state-compliance-and-head-of-state-immunity/?blogsub=confirming\#blog_subscription-2. Accessed: 19 Oct. 2020.

JACOBS, Dov. Q\&A regarding the "Q\&A REGARDING APPEALS CHAMBER'S 6 MAY 2019 JUDGMENT IN THE JORDAN REFERRAL RE AL-BASHIR APPEAL". Spreading the Jam. Available at: https://dovjacobs.com/2019/05/17/qa-regardingthe-qa-regarding-appeals-chambers-6-may-2019-judgment-in-the-jordan-referral-re-al-bashir-appeal/. Accessed: 19 Oct. 2020.

JACOBS, Dov. The Frog that Wanted to Be an Ox: The ICC's Approach to Immunities and Cooperation. In: STAHN, Carsten (org.). The law and practice of the International Criminal Court. First edition. Oxford: Oxford University Press, 2015. p. 281-304.

JACOBS, Dov. You have just entered Narnia: ICC Appeals Chamber adopts the worst possible solution on immunities in the Bashir case. Spreading the Jam. Available at: https://dovjacobs.com/2019/05/06/you-have-justentered-narnia-icc-appeals-chamber-adopts-the-worstpossible-solution-on-immunities-in-the-bashir-case/. Accessed: 19 Oct. 2020.

KALLÁS E CAETANO, Fernanda Araújo. A imunidade de jurisdição das Organizações Internacionais face ao direito de acesso à justiça. Revista de Direito Internacional, v. 13, n. 3, 2017.

KERSTEN, Mark. Not All it's Cracked Up to Be The African Union's "ICC Withdrawal Strategy". Justice in Conflict. Available at: https://justiceinconflict. org/2017/02/06/not-all-its-cracked-up-to-be-the- 
african-unions-icc-withdrawal-strategy/.

19 Oct. 2020.

KERSTEN, Mark. Sudan's Omar al-Bashir may finally face justice for Darfur. But the work is not yet done. Justice in Conflict. Available at: https://justiceinconflict. org/2020/02/21/sudans-omar-al-bashir-may-finallyface-justice-for-darfur-but-the-work-is-not-yet-done/. Accessed: 20 Oct. 2020.

KJELDGAARD-PEDERSEN, Astrid. Is the Quality of the ICC's Legal Reasoning an Obstacle to Its Ability to Deter International Crimes? iCourts Working Paper Series, n. 191, 2020. Available at: https://www.ssrn.com/ abstract $=3570447$. Accessed: 18 Oct. 2020.

KRISCH, Nico. The Backlash against International Courts. Völkerrechtsblog. Available at: https://voelkerrechtsblog.org/articles/the-backlash-against-international-courts/. Accessed: 19 Oct. 2020.

LABUDA, Patryk I. The African Union's Collective Withdrawal from the ICC: Does Bad Law make for Good Politics? EJIL: Talk! Available at: https://www. ejiltalk.org/the-african-unions-collective-withdrawalfrom-the-icc-does-bad-law-make-for-good-politics/. Accessed: 19 Oct. 2020.

LARA ABREU, Patrícia Maria; BASTOS RAPOSO, Rodrigo. Imunidade de jurisdição do Estado e reparação civil pela prática de tortura: o caso Zahra Kazemi v. República Islâmica do Irã. Revista de Direito Internacional, v. 11, n. 2, 2015.

MADSEN, Mikael Rask; CEBULAK, Pola; WIEBUSCH, Micha. Backlash against international courts: explaining the forms and patterns of resistance to international courts. International Journal of Law in Context, v. 14, n. 2, p. 197-220, 2018.

MAO, Xiao. The Function of Amicus Curiae Participation by Legal Scholars: The Al-Bashir Appeal Case at the International Criminal Court as an Illustration. Chinese Journal of International Law, v. 18, n. 2, p. 393-424, 2019.

METTRAUX, Guénaël; DUGARD, John; DU PLESSIS, Max. Heads of State Immunities, International Crimes and President Bashir's Visit to South Africa. International Criminal Law Review, v. 18, n. 4, p. 577-622, 2018. MUDUKUTI, Angela. Prosecutor v. Omar Hassan Ahmad Al-Bashir, Judgment in the Jordan Referral re
Al-Bashir Appeal. American Journal of International Law, v. 114, n. 1, p. 103-109, 2020.

MUDUKUTI, Angela. The state of play in the al-Bashir saga. Mail \& Guardian Thought Leader, 2015. Available at: https://thoughtleader.co.za/southernafricalitigationcentre/2015/09/21/the-state-of-play-in-the-al-bashirsaga/. Accessed: 12 Oct. 2020.

MURUNGI, Phoebe. 10 Years of the International Criminal Court (ICC): The Court, Africa, The United Nations Security Council (UNSC) and Article 16 of the Rome Statute. SSRN Electronic Journal, 2012. Available at: http:/ /www.ssrn.com/abstract=2169819. Accessed: 19 Oct. 2020.

NOUWEN, S. M. H.; WERNER, W. G. Doing Justice to the Political: The International Criminal Court in Uganda and Sudan. European Journal of International Law, v. 21, n. 4, p. 941-965, 2010.

NOUWEN, Sarah M.H. RETURN TO SENDER: LET THE INTERNATIONAL COURT OF JUSTICE JUSTIFY OR QUALIFY INTERNATIONALCRIMINAL-COURT EXCEPTIONALISM REGARDING PERSONAL IMMUNITIES. The Cambridge Law Journal, v. 78, n. 3, p. 596-611, 2019.

OOSTHUIZEN, Gabriël H. Some Preliminary Remarks on the Relationship Between the Envisaged International Criminal Court and the UN Security Council. Netherlands International Law Review, v. 46, n. 03, p. 313, 1999.

PAPILLON, Sophie. Has the United Nations Security Council Implicitly Removed Al Bashir's Immunity? International Criminal Law Review, v. 10, n. 2, p. 275-288, 2010.

PEDRETTI, Ramona. Immunity of heads of state and state officials for international crimes. Leiden ; Boston: Brill Nijhoff, 2015.

PILLAY, Navi; GOLDSTONE, Richard; KERSTEN, Mark. A Graceful Exit for South Africa's ICC Withdrawal Plans. Justice in Conflict. Available at: https:/ /justiceinconflict.org/2018/09/10/a-graceful-exit-for-southafricas-icc-withdrawal-plans/. Accessed: 19 Oct. 2020.

PRE-TRIAL CHAMBER I. Corrigendum to the Decision Pursuant to Article 87(7) of the Rome Statute on the Failure by the Republic of Malawi to Comply with the Cooperation Requests Issued by the Court with Respect to the Arrest and 
Surrender of Omar Hassan Ahmad Al Bashir. The Hague: International Criminal Court (ICC), 2011.

PRE-TRIAL CHAMBER I. Decision informing the United Nations Security Council and the Assembly of the States Parties to the Rome Statute about Omar Al-Bashir's presence in the territory of the Republic of Kenya. The Hague: International Criminal Court (ICC), 2010.

PRE-TRIAL CHAMBER I. Decision informing the United Nations Security Council and the Assembly of the States Parties to the Rome Statute about Omar Al-Bashir's recent visit to Djibouti. The Hague: International Criminal Court (ICC), 2011.

PRE-TRIAL CHAMBER I. Decision informing the United Nations Security Council and the Assembly of the States Parties to the Rome Statute about Omar Al-Bashir's recent visit to the Republic of Chad. The Hague: International Criminal Court (ICC), 2010.

PRE-TRIAL CHAMBER I. Decision on the Cooperation of the Democratic Republic of the Congo Regarding Omar Al Bashir's Arrest and Surrender to the Court. The Hague: International Criminal Court (ICC), 2014.

PRE-TRIAL CHAMBER I. Decision pursuant to article 87(7) of the Rome Statute on the refusal of the Republic of Chad to comply with the cooperation requests issued by the Court with respect to the arrest and surrender of Omar Hassan Ahmad Al Bashir. The Hague: International Criminal Court (ICC), 2011.

PRE-TRIAL CHAMBER I. Warrant of Arrest for Muammar Mohammed Abu Minyar Gaddafi. The Hague: International Criminal Court (ICC), 2011.

PRE-TRIAL CHAMBER II. Decision on the Prosecutor's Application for Summonses to Appear for Francis Kirimi Muthaura, Uhuru Muigai Kenyatta and Mohammed Hussein Ali. The Hague: International Criminal Court (ICC), 2011.

PRE-TRIAL CHAMBER II. Decision under article 87(7) of the Rome Statute on the non-compliance by Jordan with the request by the Court for the arrest and surrender of Omar AlBashir. The Hague: International Criminal Court (ICC), 2017.

PRE-TRIAL CHAMBER II. Decision under article 87(7) of the Rome Statute on the non-compliance by South Africa with the request by the Court for the arrest and surrender of Omar Al-Bashir. The Hague: International Criminal Court (ICC), 2017.
PRE-TRIAL CHAMBER II. Minority Opinion of Judge Marc Perrin de Brichambaut. The Hague: International Criminal Court (ICC), 2017.

PRE-TRIAL CHAMBER II. Minority Opinion of Judge Marc Perrin de Brichambaut. The Hague: International Criminal Court (ICC), 2017.

Question and Answers - Q\&A REGARDING APPEALS CHAMBER'S 6 MAY 2019 JUDGMENT IN THE JORDAN REFERRAL RE AL-BASHIR APPE$A L$. International Criminal Court (ICC). Available at: https://www.icc-cpi.int/itemsDocuments/190515-albashir-qa-eng.pdf. Accessed: 19 Oct. 2020.

REINOLD, Theresa. African Union $\mathrm{v}$ International Criminal Court: episode MLXIII (?). EJIL: Talk!! Available at: https://www.ejiltalk.org/african-union-v-international-criminal-court-episode-mlxiii/. Accessed: 19 Oct. 2020.

Rome Statute of the International Criminal Court. Rome: [s.n.], 1998.

Sudan crisis: Ex-President Omar al-Bashir moved to prison. BBC News, 2019. Available at: https://www. bbc.com/news/world-africa-47961424. Accessed: 19 Oct. 2020.

SCHABAS, William A. The Special Tribunal for Lebanon: Is a 'Tribunal of an International Character' Equivalent to an 'International Criminal Court'? Leiden Journal of International Law, v. 21, n. 2, p. 513-528, 2008.

SWART, Mia. The African Pinochet? Universal Jurisdiction and the Habré Case. In: WEILL, Sharon; SEELINGER, Kim Thuy; CARLSON, Kerstin Bree (org.). The President on Trial: Prosecuting Hissène Habré. Oxford: Oxford University Press, 2020. p. 406-415.

TLADI, D. The ICC Decisions on Chad and Malawi: On Cooperation, Immunities, and Article 98. Journal of International Criminal Justice, v. 11, n. 1, p. 199-221, 2013.

TLADI, Dire. Sudan Agrees to Send Al Bashir to the ICC: What Now for the Law? Opinio Juris. Available at: http:/ / opiniojuris.org/2020/02/12/sudan-agrees-tosend-al-bashir-to-the-icc-what-now-for-the-law/. Accessed: 20 Oct. 2020.

TRIAL CHAMBER. In re Radovan Karadžić, Ratko Mladić and Mico Stanisic, Decision in the Matter of a Proposal for a Formal Request for Deferral to the Competence of the Tribunal Addressed to the Republic of Bosnia and Herzegovina. The 
Hague: International Criminal Tribunal for the former Yugoslavia (ICTY), 1995.

TRIAL CHAMBER. Prosecutor v. Slobodan Milosevic, Decision on Preliminary Motions. The Hague: International Criminal Tribunal for the former Yugoslavia (ICTY), 2001.

TRIAL CHAMBER V. Decision on the withdrawal of charges against $\mathrm{Mr}$ Kenyatta. The Hague: International Criminal Court (ICC), 2015.

TRIFFTERER, Otto; BURCHARD, Christoph. Article 27 Irrelevance of official capacity. In: TRIFFTERER, Otto; AMBOS, Kai (org.). Rome Statute of the International Criminal Court: a commentary. Third edition. München: C.H. Beck, 2016. p. 1037-1055.

UNITED NATIONS SECURITY COUNCIL. Resolution 1593 (2005). New York: United Nations Security Council, 2005.

WEATHERALL, Thomas. Prosecutor v. Omar AlBashir, Judgment in the Jordan Referral Re Al-Bashir Appeal (Int'L Crim. Ct.). International Legal Materials, v. 58, n. 6, p. 1177-1233, 2019. Available at: https:// www.cambridge.org/core/product/identifier/ S0020782919000500/type/journal_article. Accessed: 17 Oct. 2020.

WOUTERS, Jan. The Judgement of the International Court of Justice in the Arrest Warrant Case: Some Critical Remarks. Leiden Journal of International Law, v. 16, n. 2, p. 253-267, 2003.

YAMATO, Roberto Vilchez. Mandado de Prisão de 11 de Abril de 2000 (República Democrática do Congo vs. Bélgica) (14 de Fevereiro de 2002). In: RORIZ, João Henrique Ribeiro; AMARAL JÚNIOR, Alberto do (org.). O direito internacional em movimento: jurisprudência internacional comentada: Corte Internacional de Justiça e Supremo Tribunal Federal. Brasília: IBDC, 2016. p. 115-137. 
Para publicar na Revista de Direito Internacional, acesse o endereço eletrônico www.rdi.uniceub.br ou www.brazilianjournal.org.

Observe as normas de publicação, para facilitar e agilizar o trabalho de edição. 